\title{
IMPLEMENTASI UNDANG-UNDANG NO.42 TAHUN 1999 TENTANG JAMINAN FIDUSIA TERKAIT HUKUM PERLINDUNGAN KREDITUR DALAM HAL KEPAILITAN (STUDI KASUS FIF CABANG SINGARAJA)
}

\author{
Ida Bagus Ari dwipa yoga nata, Ketut Sudiatmaka, Ni Sari Adnyani \\ Jurusan Ilmu Hukum \\ Universitas Pendidikan Ganesha \\ Singaraja, Indonesia
}

\section{Email: guzmeng21@gmail.com,Sudiatmaka@gmail.com, Niktsariadnyani@gmail.com}

\begin{abstract}
Abstrak
Penelitian ini betujuan 1) Untuk mengetahui implementasi undang-undang no 42 tahun 1999 tentang perlindungan hukum terhadap kreditur. 2) Untuk mengetahui faktor-faktor yang menyebabkan debitur terhambat dalam hal pembayran piutang. Jenis penelitian yang digunakan dalam penelitian ini adalah jenis penelitian yuridis empiris. Lokasi penelitian ini dilaksanakan di FIF tepatnya di jalan ahmad yani no.122D.Teknik pengumpulan data yang digunakan adalah, observasi dan wawancara. Teknik pengumpulan data yang digunakan adalah purposive sampling yang penentuan samplenya menggunakan teknit non probability. Data yang diperoleh diolah dan dianalisi menggunakan teknik kualitatif berdasarkan fakta yang ada untuk memperoleh jawaban atas permasalahan. Hasil penelitian menunjukan bahwa undang-undang nomer 42 taun 1999 sudah melindungi hak dan kewajiban baik pihak kreditur sebagai peminjam maupun debitur sebagai pemilik piutang, adapun factor-faktor yang mempengaruhi kreditur dalam memngembalikan pinjaman pada pihak debitur ada factor ekstrernal dan internal yang mana bisa mempengaruhi perusahaan jasa keuangan.
\end{abstract}

Kata kunci: Undang-undang No. 42 tahun 1999, jaminan fidusia, perlindungan kreditur

\begin{abstract}
This study aims at 1) To find out the implementation of Law No. 42 of 1999 concerning legal protection of creditors. 2) To find out the factors that cause debtors to be hampered in terms of payment of receivables. The type of research used in this study is a type of empirical juridical research. The location of this research was carried out at the FIF precisely at Ahmad Ahmad street No. 122D. Data collection techniques used are observation and interviews. Data collection techniques used were purposive sampling, which determined the sample using non-probability technology. The data obtained were processed and analyzed using existing fact-based qualitative techniques to obtain answers to problems. The results showed that the law number 42 year 1999 has protected the rights and obligations of both the creditor as the borrower and debtor as the owner of the receivable, as for the factors that affect the creditor in repaying the loan to the debtor there are external and internal factors which could affect the company financial services.
\end{abstract}

Keywords: Undang-undang No. 42 of 1999, fiduciary guarantee, creditor protection

\section{PENDAHULUAN}

Perkembangan ekonomi yang mana merupakan bagian dari pembangunan nasional, yang mana salah satunya untuk mensejahterakan rakyat. Dalam rangka memelihara dan meneruskan pembangunan yang berkesinambungan, para pelaku badan hukum, dipastikan memerlukan dana yang besar, sehingga dengan meningkatkan kegiatan pembangunan tersebut, maka meningkat pula keperluan akan tersedianya dana yang sebagian besar diperoleh melalui perkreditan, jasa peminjaman uang sangat penting dalam pembangunan ekonomi suatu negara.

Munculnya berbagai lembaga pembiayaan dewasa ini turut membawa andil yang besar dalam pembangunan ekonomi masyarakat khususnya masyarakat kecilkarena kegiatan pinjam meminjam uang atau yang lebih dikenal dengan istilah kredit dalam prakteknya dalam praktek kehidupan sehari-hari bukanlah merupakan suatu yang asing lagi 
bagi masyarakat awam, bahkan istilah kredit ini tidak hanya dikenal oleh masyarakat perkotaan, akan tetapi juga sampai pada masyarakat di pedesaan.

Kredit umumnya berfungsi untuk memperlancar suatu kegiatan usaha, dan khususnya bagi kegiatan perekonomian di Indonesia sangat berperan penting dalam kedudukannya, baik untuk usaha produksi maupun usaha swasta yang dikembangkan secara mandiri karena bertujuan meningkatkan taraf kehidupan bermasyarakat.

Salah satunya perusahaan
pembiayaan konsumen yang kini berkembang di Indonesia adalah PT.Federal Internasiona Finance yang merupakan anak perusahaan Astralnternasional yang mana merupakan lembaga fidusia, yang bergeraka di bidang Multy Finance dengan salah satu kantor cabang yang berada dikota Singaraja. PT.Federal Internasional Finance(FIF) dalam memberikan fasilitas pembiayaan konsumen berupa pinjaman dana Khusus hanya untuk pembeliaan kendaraan bermotor. Dalam proses pembiayaan tersebut pihak konsumen akan sanggup melunasi seluruh hutangnya. Lembaga FIF dalam jelanankan kegiatannya berpegang teguh kepada Undang-Undang Republik Indonesia Nomor 42 Tahun 1999 Tentang Jaminan Fidusia.

Kontruksi pembiayaan konsumen didasarkan pada perjanjian dengan asas kebebasan berkontra sebagai alas hukum bagi kedua belah pihak, maka para pihak harus lebih hati-hati dalam membuat perjanjian sehingga tidak merugikan para pihak atau salah satu pihak dikemudian hari serta harus memenuhi prinsip keadilan. Dalam pemberian fasilitas pembiayaan kosnumen, perusahaan pembiayaan juga memebutuhkan adanya suatu jaminan dari konsumen atau debitor. Hal itu dimaksud unutk memebrikan keyakinan dan keamanan bagi kreditor tentang adanya perhitungan yang tidak sesuai dengan yang di perjanjikan di kemudian hari yang manadebitur dalam memberikan jaminan kepada kreditur harus memenuhi kewajiban-kewajibannya dan menyerahkan hak milik atas barang jaminan tetap di kuasai oleh debitur, setelah debitur memenuhi semua kewajiban-kewajibannya, hak milik atas benda jaminan secara otomatis akan kembali kepada debitur yang mana merupakan penyerahan hak milik secara kepercayaan.

Seiring berkembangnya zaman banyak masyarakat memanfaatkan lembaga fidusia dimana dijadikan lahan modal untuk membuka usaha yang tidak jarang banyak sekali usaha tersebut mengalami kepailitan atau dalam bahasa Belanda failiet dimana seorang debitur yang mempuyai kesulitan keuangan untuk membayar utangnya lalu mengajukan surat terhadap lembaga pengadilan niaga dan dinyatakan pailit oleh pengadilan niaga, dikarenakan debitur tersebut tidak mampu atau tidak dapat membayar hutangnya lagi,lalu harta debitur dapat di bagikan kepada kreditur sesuai dengan peraturan perundangan yang berlaku, akan tetapi tidak jarang juga jikalau harta yang di bagi untuk membayar piutang terhadap kreditur masih kurang dan tidak hanya itu kadang kala ada juga kepailitan yang mana di posisinya memiliki lebih dari satu kreditur dan para krediturpun sama-sama memiliki piutang yang jumlahnya tidak sedikit. Kejadian seperti ini sering di jumpai pada zaman sekarang karena adanya atau karena dampak dari era globalisasi. FIF sebagai pihak pemberi jaminan fidusia (Kreditur) dan penerima atau pemegang jaminan fidusia adalah orang yang meminjam uang pada pihak FIF (Debitur), Adapun kasus yang terjadi di dimana debitur melakukan penundaan pembayaran dan langkah dari pihak pengelolaan kredit yang dilakukan oleh FIF dengan cara apabila mengalami keterlambatan akan di kenakan 0,5persen denda setiap melakukan keterlambatan pembayaran, dan pihak FIF juga akan selalu menghubungi debitur guna untuk mengingakan apa bila sudah mendekati tempo yang sudah di tentukan. Berdasar pengertian tentang kepailitan PKPU di atas, dapat kita simpulkan bahwa dalam kepailitan, harta debitur akan digunakan untuk membayar semua hutang-hutang yang sudah dicocokkan, sedangkan dalam 
PKPU, harta debitur akan dikelola sehingga menghasilkan dan dapat digunakan untuk membayar hutang-hutang debitur(UU Kepailitan No. 37 Tahun 2004).

Adapun hak yang perlu di lindungi dari kreditur adalah, hak untuk mendapatkan bayaran dari sejumlah piutang yang di pinjamkan pada debitur, karena seperti yang di ketahui bahwa FIF merupakan badan usaha yang bergerak dibidang penjaminan dengan meminjamkan uang dengan jaminan dan tidak berlaku untuk beberapa hal yang di atur pada pasal 3 Undang-undang No 42 Tahun 1999.

Berdasarkan latar belakang tadi ditemukan beberapa Rumusan masalah yakni 1.Bagaimana implementasi UndangUndang no 42 tahun 1999 tetang Jaminan Fidusia dalam hal perlindunganperlindungan hukum terhadap kreditur? 2. Faktor-faktor apakah yang mempengaruhi kreditur kurangmendapatperlindungan dalam hal keterlambatan dalam membayar hutang?

Tujuan dari penelitian ini adalah 1. Untuk mengetahui implementasi undang-undang no 42 tahun 1999 tentang perlindungan hukum terhadap kreditur 2. Untuk mengetahui faktor-faktor yang menyebabkan debitur terhambat dalam hal pembayaran piutang

Manfaat penelitian yang diperoleh dari penelitian ini ialah: Secara teoritis, hasil manfat penelitian ini dapat membantu perkembangan di bidang ilmu hukum khususnya dibidang keperdataandan memberikan wawasan bagi akademisi tentang bagaimana perlindungan hukum bagi kreditur yang piutangnya tidak dapat di bayar oleh debitur

\section{METODE}

Pada penelitian ini, jenis penelitian yang digunakan adalah penelitian hukum yuridis empiris. Hukum empiris adalah sebuah kajian hukum yang mengkaji law in action, yang berarti mengkaji hukum secara nyata, baik itu secara budaya maupun keadaan yang ada di lapangan. Sifat penelitian yang digunakan dalam penelitian ini adalah deskriptif, dimana menggambarkan secara nyata mengenai keadaan-keadaan atau gejala-gejala yang ada di tempat tertentu dan pada saat tertentu. Data yang digunakan adalah data primer dan data sekunder. Data primer adalah data yang diperoleh langsung dari pegawai FIF, bagian personalia Data sekunder yaitu data tata yang bersumber dari penelitian kepustakaan yaitu data yang di perlah tidak secara langsung dari sumber pertamanya, melainkan bersumber dari data-data yang sudah terdokumentasi dalam bentuk bahan-bahan hukum. Teknik Pengumpulan Data yang digunakan dalam penelitian ini adalah teknik, observasi dan wawancara. Dalam menentukan sampel, penulis menggunakan teknik non probabilitas. Cara yang digunakan untuk menentukan sampel dengan Teknik purposive sampling, yaitu penarikan sampel berdasarkan tujuan tertentu. Data pada penelitian ini diolah dan dianalisis secara kualitatif.

\section{HASIL DAN PEMBAHASAN}

Efektifitas Jaminan Fidusia dalam

hal Perlindungan Hukum terhadap kreditur Berdasar Implementasi Undang-Undang No 42 Tahun 1999 tetang Jaminan Fidusia

Didalam undang-undang no 42 tahun 1999 terlihat bahwa undang-undang sangat melindungi pihak kreditur sebagai pihak yang memegang piutang karena perjanjian. Dalam pasal 1 di nyatakan bahwa pemegang jaminan berhak memegang jaminan dan berhak menerima pembayaran sesuai dalam perjanjian, karena perjanjian yang di buat oleh kedua belah pihak mengikat layaknya undangundang. Dalam pasal 5 menegaskan bahwa akta perjanjian fidusia dibuat dengan akta notaris dan didalamnya juga berisikan tentang identitias para pihak,yang mana di berlakukannya teori efektifitas struktur hukum yang mana intansi menerapkan hukum sesuai dengan peraturan yang pernah ada sebelumnya atau sudah di tetapkan oleh pihak jasa keuangan(Finannce) yang berisikan data perjanjian pokok,uraian mengenai benda yang menjadi pokok perjanjian lalu nilai benda yang menjadi objek jaminan dan nilai penjaminan.

Pendaftaran jaminan fidusia yang dilakukan oleh pemegang jaminan fidusia dilakukan agar pemegang jaminan memiliki kekuatan eksekutorial yang sama dengan putusan pengadilan yang telah memperoleh kekuatan hukum tetap. Apabila debitor cedera janji, penerima 
fidusia mempunyai hak untuk menjual benda yang menjadi objek jaminan fidusia atas kekuatan sendiri, itu juga telah di tegaskan pada pasal 15.Pada pasal 8 di tegaskan bawa pemberi fifusia kepada lebih dari satu penerima fidusia dalam rangka pembiayaan kredit konsosium. Yang dimaksud dengankuasa" adalah orang yang mendapatkan kuasa khusus dari penerima fidusia untuk mewakili kepentingannya dalam penerima jaminan fidusia dari pemberi fidusia. Yang di anggap dimaksud dengan "wakil" adalah orang yang secara hukum dianggap mewakili penerima fidusia dalam penerima jaminan fidusia, misalnya, wali amanat dalam mwakili kepentingan pemegang obligasi

Pada pasal 37 ayat 3 menjelaskan berdasar pada ayat ini maka perjanjian jaminan fidusia yang tidak didaftar tidak mempunyai hak yang didahulukan (preferenu) baik didalam maupun diluar kepailitan dan atau likuidasi.Pada pasalpasal di atas sudah di jelaskan bahwa pada undang-undang nomer 42 tahun 1999 sudah benar-benar melindungi para pihak yang melakukan perjanjian fidusia sehingga dapat meminimalisir kecurangankecurangan atau memanfaatkan celahcelah hukum yang ada yang akan dilakukan oleh pihak yang ingin mencari keuntungan atau melanggar penjanjian yang ada dan tidak hanya ituperlindungan hukum bagi pihak kreditur dalam perjanjian kredit dengan jaminan fidusia sangat diperlukan, mengingat benda yang menjadi objek jaminan fidusia berada pada pihak debitur, sehingga apabila debitur melakukan wanprestasi terhadap perjanjian kredit dengan jaminan fidusia, kepentingan kreditur dapat terjamin dengan adanya perlindungan hukum tersebut.Perlindungan hukum terhadap kreditur ini diatur secara umum, yaitu: diatur dalam KUH Perdata Pasal 1131 dan 1132 dan Undang-undang No.42 Tahun 1999 tentang Jaminan Fidusia. Pasal 1131 KUH Perdata menyebutkan, "segala kebendaan, baik yang sudah ada maupun yang baru aka nada dikemudian hari, menjadi tanggungan untuk segala perikatan perseorangan."
Pasal diatas dapat diartikan, sejak seseorang mengikatkan diri pada suatu perjanjian maka sejak itu semua harta kekayaan baik yang sudah ada maupun yang baru aka nada di kemudian hari menjadi tanggungan untuk segala perikatannya. Pasal 1132 KUH Perdata menyebutkan "kebendaan tersebut menjadi jaminan bersama-sama bagi semua orang yang mengutangkan kepadanya, pendapatan penjualan benda-benda itu dibagi-bagi menurut keseimbangan, yaitu menurut besar kecilnya piutang masingmasing, kecuali apabila diantara para berpiutang itu ada alasan-alasan yang sah didahulukan." Pasal ini menjelaskan bahwa harta kekayaan debitur menjadi jaminan bagi para krediturnya. Hasil penjualan dibagi menurut imbangan masing-masing kecuali ada hak untuk didahulukan.

Undang-undang No.42 Tahun 1999 dalam hal ini menjelaskan perlindungan hukum bagi para pihak yang berkepentingan dalam perjanjian kredit dengan jaminan fidusia, dengan kata lain Undang-undang yang secara khusus mengatur tentang jaminan fidusia, Pasal 11, 14, dan 15 Undang-undang Nomor 42 Tahun 1999 yang pada intinya menyebutkan bahwa benda yang dibebani dengan jaminan fidusia wajib didaftarkan kemudian dibuat sertifikat jaminan fidusia yang mencantumkan irah-irah "DEMI KEADILAN DAN KETUHANAN YANG MAHA ESA", sehingga sertifikat jaminan fidusia mempunyai kekuatan eksekutorial yang sama dengan putusan pengadilan yang telah memperoleh kekuatan hukum tetap.

Kreditur mempunyai hak untuk
melaksanakan title eksekutorial
sebagaimana tercantum dalam sertifikat
jaminan fidusia, apabila debitur
wanprestasi. Kreditur juga mempunyai hak
untuk menjual benda yang menjadi objek
jaminan fidusia melalui pelelangan umum
serta pelunasan piutang dari hasil
penjualan atau penjualan dibawah tangan
yang dilakukan berdasarkan kesepakatan
bersama antara kreditur dan debitur.
Undang-undang Nomor 42 Tahun 1999 ini
juga mengatur mengenai ketentuan pidana
bagi pemberi fidusia atau debitur yang


mengalihkan, mengendalikan, atau menyewakan benda yang menjadi objek jaminan fidusia yang dilakukan tanpa persetjuan tertulis terlebih dahulu dari penerima fidusia atau kreditur. Maka dapat dipidana dengan pidana penjara paling lama 2 tahun dan denda paling banyak sebebsar Rp.50.000.000,00 (Lima puluh juta rupiah).

\section{Faktor-faktor yang Mempengaruhi Kreditur Kurang Mendapat Perlindungan dalam hal Keterlambatan dalam Membayar Hutang.}

Seringnya kredit macet yang di alami oleh lembaga lembaga keuangan sangat mempengaruhi perusahaan ataupun lembaga keuangan itu sendiri dan bahkan bisa saja menyebabkan kebangkrutan lembaga keuangan. Sesai hasil penelitian saya yang saya lakukan pada lembaga jasa keuangan FIF cabang Singaraja dimana di setiap tahunnya ada banyak debitor yang macet dalam hal pembayaran kreditnya sehingga menggangu perputaran uang yang ada pada jasa keuangan, yang mana kita ketahui kalau jasa keuangan seperti FIF mendapatkan keuntungan berupa bunga yang disetorkan oleh para debitor. Walaupun sudah diikat dengan fidusia yang berfungsi sebagai mitigasi(upaya menekan resiko) masih saja ada debitor yang macet dalam pembayaran. FIFyang merupakan jasa keuangan meskipun berbentuk swasta tetap berada dibawah pengawasan OJK (Otoritas JasaKeuangan ).

Otoritas Jasa Keuangan

adalahlembaga independen dan bebas dari campur tangan pihak lain, yang mempunyai fungsi, tugas, dan wewenang pengaturan, pengawasan, pemeriksaan, dan penyidikan. OJK dibentuk berdasarkan UU Nomor 21 Tahun 2011 yang berfungsi menyelenggarakan sistem pengaturan dan pengawasan yang terintegrasi terhadap keseluruhan kegiatan di dalam sektor jasa keuangan.Otoritas Jasa Keuangan didirikan untuk menggantikan peran Bapepam-LKdalam pengaturan dan pengawasan pasar modal dan lembaga keuangan, serta menggantikan peran $\mathrm{BI}$ (Bank Indonesia) dalam pengaturan dan pengawasan bank, serta untuk melindungi konsumen industri jasa keuangan.

Banyaknya debitor yang macet dalam melakukan pembayaran menyebabkan meningkatnya presentasinya non performingloans atau biasa di sebut NPL ini merupakan kredit bermasalah yang merupakan salah satu kunci untuk menilai kualitas kinerja jasa keuangan. Ini artinya NPL merupakan indiakasi adanya masalah dalam jasa keuangan tersebut yang mana jika tidak segera mendapatkan solusi maka akan berdampak bahaya pada jasa keuangan.

Bagaimana tidak, meningkatnya NPL ini jika dibiarkan secara terus menerus akan memberikan pengaruh negatif pada jasakeuangan. Dampak negatif tersebut salah satunya adalah mengurangi jumlah modal yang dimiliki oleh jasakeuangan tersebut.

Suku bunga memang merupakan salah satu sumber income dari jasa keuangan yang mana jika jasa keuangan tidak lagi menerima angsuran sesuai dengan jangka waktu yang telah ditentukan, maka dikhawatirkan hal ini akan terus memperburuk kondisi pihak jasa keuangan.Melihat kasus seperti ini, maka pihak jasa keuangan memang dituntut untuk melakukan analisa kredit sehingga bisa melakukan seleksi klien mana yang pantas untuk menerima dana pinjaman dari bank.

Faktor -faktor pemicu NPL padi lembaga keuangan Banyak faktor yang seringkali memicu munculnya masalah ini diantaranya adalah dampak krisis mulit dimensional yang hingga saat ini membuat banyak dari para debitur yang tidak mampu menyelesaikan masalah kredit mereka yang macet.

Faktor lain yang juga seringkali memicu masalah ini adalah tidak adanya i'tikad baik dari para debitur untuk segera menyelesaikan masalah ini. Yang mana akan berujung pada penggerusan modal awal bahkan bisa saja sampai dengan istilah cash flow dan tidak bisa di pungkiri biaya oprasional harus tetap bejalan, dan sepertiyang kita ketahui FIF sendiri perlu mendapatkan untung karena dari bunga yang di dapatkan pihak FIF selaku Kreditor 
melalui peminjaman uang harus membiayayai likuiditas (pembiayaan jangka pendek), Likuiditas diukur dengan rasio aktivitas lancar dibagi dengan kewajiban lancar. Perusahaan yang memiliki likuiditas sehat paling tidak memiliki rasio kelancara sebesar $100 \%$. Ukuran likuiditas perusahaan yang lebih menggambarkan tingkat likuiditas perusahaan ditunjukkan dengan rasio kas (kas terhadap kewajiban lancar).Contoh: pembayaran pajak, membayar listrik, telepon,pembayran air PDAM, gaji karyawan atau bahkan FIF harus melakukan pembayaran kepada pihak pemberi pinjaman atau biasa di sebut DPK(Dana Pihak Ketiga)

Akibatnya tidak jarang bank atau lembaga keuangan akan menerima dampaknya dari kondisi ini. Tingginya suku bunga memang seringkali menjadi masalah atau beban berat bagi para debitor untuk menyelesaikan kewajiban mereka pada pihak jasa keuangan, sehingga mereka tidak mampu menyelesaikan kredit sesuai dengan kesepakatan yang telah dibuat.

Mengetahui seluk beluk mengenai apa itu non performing loan tampaknya hal itu tidak cukup dalam dunia perbangkan. Untuk menjaga bank tetap dalam kondisi yang aman, maka sistem manajemen yang baik memang sangat perlu untuk diterapkan secara maksimal.

Melalui manajemen yang baik dalam berbagai kegiatan operasional jasa keuangan terutama untuk hal-hal yang terkait dengan kredit ini, akan membantu menjaga kestabilan kondisi dalam FIF. sebagaimana yang telah kita singgung di atas bahwa NPL bisa memberikan pengaruh besar pada jasa keuangan.NPL yang juga dikenal dengan kredit bermasalah ini memang bisa berdampak pada berkurangnya modal bank. Jika hal ini dibiarkan, maka yang pasti akan berdampak pada penyaluran kredit pada periode berikutnya.

Bayangkan saja jika peminjam dana bank tidak lagi memenuhi kewajiban mereka membayar angsuran, maka pastinya jasa keuangan akan kehilangan sumber incomenya. Akibatnya, kondisi seperti ini akan mengurangi kondisi deviden dan juga laba.

Hal-hal berikut ini merupakan faktor-faktor yang mempengaruhi atau bahkan naik turunnya NPL itu sendiri, diantaranya adalah bukan kemauan dari para debitur, kondisi perekonomian Indonesia, dan juga kebijakan dari pemerintah. Sebagaimana fungi FIF sebagai lembaga jasa keuangan yang memang difungsikan untuk menghimpun dan juga menyalurkan dana dari dan untuk rakyat. Untuk memaksimalkan hal ini dan tetap terkoordinir dengan baik, maka pihak jasa keuangan memang harus membuat sistem manajemen pada berbagai aspek dan pihak yang terlibat. Langkah ini merupakan upaya yang cukup bagus dalam melakukan manajemen seluruh kegiatan operasional lembaga keuangan, diantaranya adalah untuk mengurangi resiko gagal kredit atau kredit macet yang akhirnya bisa menyebabkan FIF tidak sehat.

Jika bicara mengenai perlindungannya terhadarp Debitor yang mana FIF sebagai lembaga jasa keuangan yang meminjamkan uang sesuai yang di atur di dalma pasal 42 tahun 1999 sudah sangan di lindungi seperti yang sudah di jelaskan pada pembahsan rumusan masalah yang pertama hanya yang masih menjadi kendala adalah kesadaran dari pihak kreditur sebagai peminjam.

Beberapa ahli juga sempat menyatakan bahwa secara garisbesar ada 2(dua) factor penyebab keterlambatan pembayran yang di lakkan oleh pihak peminjam atau debitur yang mana sebagai berikut

Faktor internal yang merupakan tejadinya kredit macet bisa berupa,Terjadinya penyimpangan pada pelaksanaan prosedur kreditnya etika yang kurang baik, baik dari pihak pemiliknya, pengurus atau sebagai pegawai perbankan, pemberian informasi kredit yang kurang jelas maupun lambat sistem administasi dan pengawasan yang lamah terhadap pengkreditan

Faktor kestrnal,Kegagalan usahanasabahyang mana terjadinya musibah pada sistem seperti contoh tenggelamnya kapal usaha milik debitor 
yang di pakai untuk mencari ikan(alat usaha) sehingga terjadinya cash flow yang menyebabkan pinjaman bunga bank tinggi

Kreditdi Indonesia dikenal memiliki dua golongan kredit, yaitu kredit lancar dan kredit bermasalah.Di mana kredit bermasalah digolongkan menjadi tiga, yaitu kredit kurang lancar, kredit diragukan, dan kredit macet. Kredit macet inilah yang sangat dikhawatirkan oleh setiap Finance dan bank atau jasa keuangan, karena akan mengganggu kondisi keuangan dan perputaran uang dari jasa keuangan itu sendiri, bahkan dapat mengakibatkan berhentinya kegiatan usaha jasa keuangan.

Finance atau bank yang memiliki fungsi sebagai penyedia jasa keuangan dalam perkembangannya bisa saja mengalami fase Non Performance Loan (NPL) atau dalam bahasa umum biasa disebut Kredit Macet. Keadaan semacam ini sangat berpotensi menghambat perkembangan pihak Bank selaku penyedia jasa keuangan.

Kredit Macet ini disebabkan oleh berbagai macam faktor yang sangat berpengaruh terhadap kestabilan perbankan, namun pada dasarnya hanya ada 2 Faktor Utama penyebab Kredit Macet, yaitu:

Faktor Eksternal

Kredit macet atau problem loan adalah kredit yang mengalami kesulitan dalammelakukan kewajiban dalam halpelunasan akibat adanya faktor-faktor atau unsur kesengajaan atau karena kondisi di luar kemampuan debitur..

Debitur atau nasabah dalam hal ini adalah sebagai pihak luar yang tidak sedikit dari mereka mengalami kondisi penurunan keuangan, usaha yang dijalankan oleh nasabah tidak stabil atau bisa jadi ada faktor kesengajaan dalam pembayaran tagihan yang tidak tepat waktu.

Selain kegagalan usaha debitur atau faktor kesengajaan dari debitur seperti disebut di atas, menurunnya kegiatan ekonomi dan tingginya suku bunga kredit juga mempengaruhi kestabilan bank. Hal semacam ini seharusnya mudah untuk dicegah, cukup pantau keadaan sebuah
perusahaan.Apabila terjadi penundaan yang tidak normal dalam penerimaan laporan keuangan, pembayaran cicilan atau dokumen lainnya.Kemudian ada penyelidikan yang tidak terduga dari lembaga-lembaga keuangan lainnya mengenai nasabah tersebut. Dampak kerugian dari Kredit Macet (Non Performance Loan) tidak hanya dirasakan oleh nasabah saja, pihak bank selaku penyedia jasa keuangan juga akan mengalami kerugian. Sebagaimana kita ketahui dampak negatif yang dirasakan oleh nasabah adalah nasabah harus menanggung kewajiban kepada bank. Mengingat setiap pinjaman dari bank (konvensional) memiliki bunga yang cukup memberatkan nasabah, maka jumlah kewajiban nasabah semakin lama akan semakin bertambah besar jika belum dilunasi.

Sedangkan dampak negatif yang dialami oleh pihak bank jauh lebih serius, karena selain dana yang disalurkan untuk kredit berasal dari masyarakat dan negara, kredit macet juga mengakibatkan bank kekurangan dana sehingga mempengaruhi kegiatan usaha bank.Dibalik masalah Kredit Macet yang menghantui kedua belah pihak baik dari pandangan sebagai nasabah atau pandangan sebagai bank, tentunya ada cara penyelesaian yang dapat ditempuh oleh keduanya sebagai solusi agar terhindar dari fase terburuk yang bisa saja dialami oleh kedua pihak. Sebagai pengingat, ada banyak peristiwa krisis keuangan yang telah terjadi di Indonesia.

Kasus Century yang terjadi pada tahun 2008 akibat penyelewengan dana nasabah dan tragedi kerusuhan pada tahun 1998 dimana perekonomian Indonesia berada pada titik terburuk. Dua peristiwa tersebut sama-sama memiliki dampak negatif terhadap nasabah maupun pihak bank.Kesimpulan yang dapat diambil dari masalah kredit macet ini adalah masyarakat selaku nasabah yang telah dibantu oleh pihak bank diharapkan dapat menanamkan sikap disiplin dalam membayar setiap tagihan.Lebih teliti dalam membaca perjanjian kredit (akad kredit) sebelum menandatangani (menyetujui) 
perjanjian kontrak yang diberikan oleh pihak bank.

Perhatikan poin-poin penting yang tertera dalam surat perjanjian tersebut, seperti Annual Fee (luaran Tahunan) yang biasanya dibebankan pada nasabah. Dan pihak Bank selaku penyedia jasa keuangan diharapkan dapat meningkatkan kredibilitas tim penganalisa riwayat calon kreditur. Memperbaiki ketepatan waktu dalam merealisasikan pengajuan kredit, karena nasabah juga memiliki jadwal sendiri dalam mengatur pengeluaran.

Pengaturan dalam Pasal 281 ayat (2) UU No. 37 Tahun 2004 tentang Kepailitan dan Penundaan Kewajiban Pembayaran Utang ("UUK") berbunyi sebagai berikut:"Kreditor sebagaimana dimaksud pada ayat (1) huruf b yang tidak menyetujui rencana perdamaian diberikan kompensasi sebesar nilai terendah di antara nilai jaminan atau nilai aktual pinjaman yang secara langsung dijamin dengan hak agunan atas kebendaan."

Merunut pada sistematika UUK, maka ketentuan Pasal 281 ayat (1) UUK tersebut adalah dalam konteks Penundaan Kewajiban Pembayaran Utang (PKPU). Pasal tersebut mengatur proses voting di antara para kreditor untuk setuju atau tidak setuju terhadap proposal perdamaian yang diajukan oleh Debitor mengenai bagaimana utang tersebut akan dibayar. Rencana perdamaian itu sendiri bisa berupa penjadwalan ulang pembayaran utang, pembayaran angsuran atau bisa juga meminta diskon atas nilai tagihan utang.Pada intinya Pasal 281 (1) UUK mengatur bahwa rencana perdamaian dapat diterima dengan syarat apabila dalam voting tersebut disetujui secara bersama-sama oleh; (a) mayoritas kreditor konkuren yang hadir dalam rapat kreditor dan; (b) mayoritas kreditor separatis yang hadir dalam rapat kreditor.

Namun demikian, hal terpenting dari Pasal 281 (1) UUK adalah adanya persetujuan dari mayoritas kreditor separatis adalah mutlak.Karena walaupun seluruh kreditor konkuren menyetujui usul perdamaian, namun jika mayoritas kreditor separatis menolak perdamaian, maka rencana perdamaian wajib ditolak. Secara logis hal tersebut dapat digambarkan bahwa debitor akan mengalami kesulitan untuk memenuhi kewajibannya apabila hartanya dieksekusi oleh mayoritas kreditor separatis yang tidak menyetujui dan tidak terikat ke dalam perjanjian perdamaian.

Berlanjut kepada Pasal 281 ayat (2) UUK, pada pokoknya pasal tersebut mengatur bahwa minoritas kreditor separatis yang tidak menyetujui rencana perdamaian dapat memperoleh kompensasi (penggantian) sebesar nilai terendah antara nilai jaminan atau nilai aktual pinjaman.Hal tersebut dimaksudkan dalam rangka memberikan perlindungan terhadap rencana perjanjian perdamaian yang sudah disepakati oleh debitor dan mayoritas kreditor separatis maupun konkuren sehingga jangan sampai minoritas kreditor separatis melakukan eksekusi sendiri terhadap harta debitor yang dapat mengganggu pelaksanaan perjanjian perdamaian yang telah disepakati.

Kemudian Pertanyaan berikutnya, bagaimana jika nilai jaminannya jauh lebih rendah daripada nilai pinjaman, ke mana sisa utangnya?

Dari pertanyaan tersebut dapat ditafsirkan bahwa kreditor tersebut memiliki piutang yang pelunasannya sebagian dijamin dengan harta debitor.Sehingga dari hal tersebut kreditor tersebut memiliki tagihan konkuren dan tagihan separatis. Untuk tagihan separatis, apabila kreditor tersebut menolak usulan perdamaian, maka akan memperoleh kompensasi (penggantian) sesuai dengan Pasal 281 ayat (2) UUK. Sedangkan untuk tagihan konkuren, walaupun kreditor tersebut menolak rencana perdamaian, maka sisa utangnya tetap ada namun secara hukum harus terikat dan tunduk dalam perjanjian perdamaian karena sifat tagihannya yang konkuren yang harus mengikuti ketentuan Pasal 286 UUK yang berbunyi sebagai berikut:"Perdamaian yang telah disahkan, mengikat semua kreditor, kecuali Kreditor yang tidak menyetujui rencana perdamaian sebagaimana dimaksud dalam Pasal 281 ayat (2)"

Perlindungan hukum bagi pihak kreditur dalam perjanjian kredit dengan 
jaminan fidusia sangat diperlukan, mengingat benda yang menjadi objek jaminan fidusia berada pada pihak debitur, sehingga apabila debitur melakukan wanprestasi terhadap perjanjian kredit dengan jaminan fidusia, kepentingan kreditur dapat terjamin dengan adanya perlindungan hukum tersebut.

Perlindungan hukum terhadap kreditur ini diatur secara umum, yaitu: diatur dalam KUH Perdata Pasal 1131 dan 1132 dan Undang-undang No.42 Tahun 1999 tentang Jaminan Fidusia. Pasal 1131 KUH Perdata menyebutkan, "segala kebendaan, baik yang sudah ada maupun yang baru aka nada dikemudian hari, menjadi tanggungan untuk segala perikatan perseorangan."Pasal diatas dapat diartikan, sejak seseorang mengikatkan diri pada suatu perjanjian maka sejak itu semua harta kekayaan baik yang sudah ada maupun yang baru aka nada di kemudian hari menjadi tanggungan untuk segala perikatannya.

$$
\text { Pasal } 1132 \mathrm{KUH} \text { Perdata }
$$

menyebutkan "kebendaan tersebut menjadi jaminan bersama-sama bagi semua orang yang mengutangkan kepadanya, pendapatan penjualan benda-benda itu dibagi-bagi menurut keseimbangan, yaitu menurut besar kecilnya piutang masingmasing, kecuali apabila diantara para berpiutang itu ada alasan-alasan yang sah didahulukan."Pasal ini menjelaskan bahwa harta kekayaan debitur menjadi jaminan bagi para krediturnya.Hasil penjualan dibagi menurut imbangan masing-masing kecuali ada hak untuk didahulukan.

Undang-undang No.42 Tahun 1999 dalam hal ini menjelaskan perlindungan hukum bagi para pihak yang berkepentingan dalam perjanjian kredit dengan jaminan fidusia, dengan kata lain Undang-undang yang secara khusus mengatur tentang jaminan fidusia, Pasal 11, 14, dan 15 Undang-undang Nomor 42 Tahun 1999 yang pada intinya menyebutkan bahwa benda yang dibebani dengan jaminan fidusia wajib didaftarkan kemudian dibuat sertifikat jaminan fidusia yang mencantumkan irah-irah "DEMI KEADILAN DAN KETUHANAN YANG MAHA ESA", sehingga sertifikat jaminan fidusia mempunyai kekuatan eksekutorial yang sama dengan putusan pengadilan yang telah memperoleh kekuatan hukum tetap.

Kreditur mempunyai hak untuk melaksanakan title eksekutorial sebagaimana tercantum dalam sertifikat jaminan fidusia, apabila debitur wanprestasi.Kreditur juga mempunyai hak untuk menjual benda yang menjadi objek jaminan fidusia melalui pelelangan umum serta pelunasan piutang dari hasil penjualan atau penjualan dibawah tangan yang dilakukan berdasarkan kesepakatan bersama antara kreditur dan debitur. Undang-undang Nomor 42 Tahun 1999 ini juga mengatur mengenai ketentuan pidana bagi pemberi fidusia atau debitur yang mengalihkan, mengendalikan, atau menyewakan benda yang menjadi objek jaminan fidusia yang dilakukan tanpa persetjuan tertulis terlebih dahulu dari penerima fidusia atau kreditur. Maka dapat dipidana dengan pidana penjara paling lama 2 tahun dan denda paling banyak Rp.50.000.000,00.

\section{SIMPULAN DAN SARAN}

Berdasarkan hasil penelitian dan pembahasan mengenaiefektifitas undangundang no 42 tahun 1999 tentang jaminan fidusia terkait hukum perlindungan kreditur dalam hal kepailitan dapat di simpulkan sebagai berikut:

1.Mekanisme perlindungan terlihat bahwa undang-undang sangat melindungi pihak kreditur sebagai pihak yang memegang piutang karena perjanjian. Dalam pasal 1 dinyatakan bahwa pemegang jaminan berhak memegang jaminan dan berhak menerima pembayaran sesuai dalam perjanjian, karena perjanjian yang di buat oleh kedua belah pihak mengikat layaknya undangundang dan di atur juga pada pasal-pasal dari pasal 8 di tegaskan bawa pemberi fifusia kepada lebih dari satu penerima fidusia dalam rangka pembiayaan kredit. sampai dngan 37 tersebut menjelaskan berdasar pada ayat ini maka perjanjian jaminan fidusia yang tidak didaftar tidak mempunyai hak yang didahulukan sepeti yang saya jelaskan pada pebahasan 
2. Faktor-faktor yang Mempengaruhi Kreditur Kurang Mendapat Perlindungan dalam hal Keterlambatan dalam Membayar HutangSeringnya kredit macet yang di alami oleh lembaga lembaga keuangan sangat mempengaruhi perusahaan ataupun lembaga keuangan itu sendiri dan bahkan bisa saja menyebabkan kebangkrutan lembaga keuangan. Sesuai hasil penelitian saya yang saya lakukan pada lembaga jasa keuangan FIF cabang Singaraja dimana di setiap tahunnya ada banyak debitor yang macet dalam pembayaran kredit yang mana menyebabkan banyaknya angka dalam NPL dan menyebabkan perputaran uang dalam jasa keuangan terganggu sehingga penilaiaan OJK terhadap jasakeuangan tersebut kurang baik dalam hal pengembangannya yang di sebabkan oleh banyaknya kredit macet yang di alami olej FIF cabang Singaraja dan adapunKredit Macet ini disebabkan oleh berbagai macam faktor yang sangat berpengaruh terhadap kestabilan perbankan, namun pada dasarnya hanya ada 2 Faktor Utama penyebab Kredit Macet

Adapun saran bagi pihak debitur atau jasa keuangan yang mana dalam memberikan kredit terhadap debitur harus lebih hati-hati dalam mencairkan uang kredit yang mana harus jelas jaminannya dan harus di daftarkan agar apabila terhajdi hal yang tidak di inginkan seperti kredit macet pihak kreditur mendapat perlindungan lebih dari undang-undang yang mana bisa membahayakan lambatnya perputaran uangyangada dan adapun saran bagi debitur harus hati-hati dalam hal meminjam kredit kepada jasa keuangan karena harus banyak yang di pertimbangkan karena apa bila debitur macet dalamhal pembayaran pihak kreditur berhak mengambil jaminan yang sudah diperjanjikan sebelumnya sesuai ketentuan yang ada.

\section{DAFTAR PUSTAKA}

Ahmadi Miru,.., 2008, Penjelasan makna pasal 1233 sampai $1456 \mathrm{BW}$, PT RajaGrafindo Persada, Jakarta
Moch. Isnaeni, 2016,Pengantar hukum jaminan kebendaan, LaksBang PRESSindo, Yogyakarta

Zaini Diane,2014,Aspek hukum dan fungsi lembaga penjamin simpanan, Keni Media, Bandung

Yudha Pandu. 2008. Himpunan Peraturan Perundang-undagan Jaminan Fidusia dan Hak Tanggungan. Jakarta Indonesia Legal Center Publishing.

R.Subekti 1991. Jaminan-jaminan untuk Pemberian Kredit menurut Hukum Indonesia.Bandung. PT. Citra Aditya Bakti

2008 , Himpunan peraturan perundang undangan jaminan fidusia \& hak tanggungan,INDONESIA LEGAL CENTER PUBLISHING 